\title{
Article \\ Complaints as Opportunity for Change in Encounters between Youths and Police Officers
}

\author{
Tove Pettersson \\ Department of Criminology, Stockholm University, 10691 Stockholm, Sweden; \\ E-Mail: tove.pettersson@criminology.su.se; Tel.: +46-8-674-70-53
}

Submitted: 7 April 2014 | In Revised Form: 19 June 2014 | Accepted: 24 June 2014 | Published: 17 September 2014

\begin{abstract}
The presence of distrust in the police and how they perform their work among ethnic minority youths in socially underprivileged areas is well established. Experiences of, or beliefs about, unfair treatment from the police can be viewed both as an indicator and a consequence of exclusion. It is well-known that negative experiences of the police are more significant for trust in the police and their legitimacy than positive ones, with some even suggesting that positive experiences do not matter at all. However, from a procedural justice perspective it has been suggested that some positive experience do matter, particularly if the police are considered to perform their work in line with procedural fairness. On the basis of a participant observation study, this article discusses situations in which youths express complaints about the police in different ways. In response to such situations, the police can act in both exclusionary and inclusive ways. It is argued that youths' complaints can be used as an opportunity for change if the police treat the youths concerned with fairness and in inclusive rather than exclusionary ways.
\end{abstract}

\section{Keywords}

ethnic minorities; police; procedural justice; youths

\section{Issue}

This article is part of the special issue "Policing Ethnicity: Between the Rhetoric of Inclusion and the Practices and Policies of Exclusion", edited by Professor Abby Peterson (University of Gothenburg, Sweden) and Professor Malin Åkerström (University of Lund, Sweden).

(C) 2014 by the author; licensee Cogitatio (Lisbon, Portugal). This article is licensed under a Creative Commons Attribution 4.0 International License (CC BY).

\section{Introduction}

The work of policing is powerfully shaped by the dimensions of gender and geography. This means, amongst other things, that policing often takes the form of exercising controls in relation to young men from ethnic minorities in areas with social problems (Bowling \& Weber, 2011; Brunson, 2007). One consequence of this is an increased level of distrust in the police in these areas, perhaps primarily on the part of young men from ethnic minorities (Brunson \& Miller, 2006; Brunson, 2007). Research on what influences perceptions of the police has shown that the issue is a complex one, but having negative experiences of the police oneself, or hearing about others' negative experiences, have shown themselves to be important fac- tors (Brunson, 2007; Brunson \& Miller 2006; Skogan, 2012), as have perceptions of ethnic discrimination on the part of the police (Brunson \& Miller, 2006; Brunson, 2007; Weitzer \& Tuch, 2002) and of discrimination in society at large (Brunson \& Miller, 2006; Sharp \& Atherton, 2007; Weitzer \& Tuch, 2002). Skogan (2012) found that negative behavior from police officers is strongly related to distrust in the police, whereas positive behavior is much less associated with a corresponding trust in or positive opinion of the police. However, this view has been contradicted by research focused on a procedural justice perspective, which has found that when the behavior of police officers follows the demands of procedural fairness, this is associated with improving opinions of the police (Murphy \& Cherney, 2012; Sunshine \& Tyler, 2003; Tyler, 2006; Brad- 
ford, Jackson, \& Stanko, 2009; Sargeant, Murphy, \& Cherney, 2014; Bradford, 2014).

Much of the research that has been conducted in this area is either quantitative, with the limitations of quantitative research regarding a more nuanced understanding of the meaning of perceptions and experiences, or based solely on interviews (Brunson, 2007). This article contributes by using data from interactions between police officers and youths. The purpose of the article is to analyse situations where youths complain about police treatment, either in the situation itself or in general. The article analyses both the youths' reactions and the police officers' responses to these reactions. It contributes to the procedural justice perspective by focusing on processes within encounters and on the importance of non-verbal interaction, both of which are rare within the field.

\section{Previous Research}

Existing research on the relationship between police officers and ethnic minorities is extensive. Studies of discrimination have focused both on attitudes and on disproportionalities in the focus police activity, showing that ethnic minorities are subject to disproportionately high levels of police attention (Brunson \& Miller, 2006; Chan, 1997; Petrocelli, Piquero, \& Smith, 2003; Quinton, 2013; Reiner, 2000; Weitzer \& Tuch, 2002; Wortley \& Owusu-Bempah, 2013). It is first and foremost young males from ethnic minorities who are subject to discrimination on the part of the police (Steffensmeier, Ulmer, \& Kramer, 1998; Reitzel \& Piquero, 2006). This study looks beyond ethnic discrimination per se, and focuses on interactions between youths and police officers in which the youths express complaints about the police. ${ }^{1}$ However, issues of discrimination may still be central to these experiences, since the youths in the study are mostly from areas where opinions about the police are often coloured by experiences and feelings of exposure to unfair treatment due to e.g. the youths' ethnicity and the area in which they live (Hallin et al., 2010; Sernhede, 2007; Bowling \& Weber, 2011).

Studies examining ethnic minorities' perceptions of the police have often focused on adults, but there are some exceptions, such as Hurst, Frank, and Browning (2000), Brunson and Miller (2006), Carr, Napolitano, and Keating (2007), Dirikx, Gelders, and Parmentier (2012), and Sharp and Atherton (2007). Findings suggest that the police enjoy less legitimacy among ethnic minority youths than among other categories. An exception to this is the study by Carr et al. (2007) which found substantial similarities among the youths who were interviewed, irrespective of their backgrounds.

${ }^{1}$ Either to the police themselves or, sometimes, to me in my role as a field researcher.
However, all of the youths included in the current study came from socially disadvantaged areas, which may be a reason for the similarities, since dissatisfaction with the police is also correlated with neighbourhood characteristics (Brunson, 2007, p. 74).

Carr et al. (2007) note that despite the fact that many of the youths whom they interviewed harboured negative perceptions about the police, they nonetheless stated at a general level that the police had a very important role to fill in relation to the control of crime. Carr et al. emphasise that there is a substantial potential for cooperation between youths and the police, provided that the youths in question perceive the police as professional, dedicated and honest (see also Bradford, 2014). This is similar to other studies, where feelings of not being met with respect are identified as one of the most important reasons for negative opinions of the police (Brunson \& Miller, 2006; Sharp \& Atherton, 2007; Wahlström, 2008).

One perspective that highlights the importance of the way people are treated by the authorities, in this case the police, is the procedural justice perspective (Bradford et al., 2009; Bradford, 2014; Hough at al., 2010; Murphy \& Cherney, 2012; Sunshine \& Tyler, 2003; Tyler, 2006; Sargeant et al., 2014), and this will therefore guide my analysis.

The procedural justice model focuses on the legitimacy of legal authorities and on whether the public are willing to cooperate with them. Trust in the police is important in relation to both of these issues. Cooperation is not, as the concept might suggest, about doing what you are told by the police, but is rather about whether you would call the police to report a crime, help the police to find a suspect or provide them with information about a crime, or be willing to assist the police if asked (Murphy \& Cherney, 2012; Sunshine \& Tyler, 2003). The police are highly dependent on the public in these matters in relation to their ability to conduct their work. The hypothesis, which has found support in several studies, is that "public perceptions of the fairness of the justice system [...] are more significant in shaping its legitimacy than perceptions that it is effective" (Hough et al., 2010, p. 205). An important distinction is made between justice based on process or outcome, with the process being more important than the outcome; that is, being given fair and respectful treatment that 'follow the rules' (the quality of treatment) seems to be more important for public opinions about the legitimacy of the police (whether the policed view the police as legitimate) than the outcome of the police's work. ${ }^{2}$

\footnotetext{
2 This finding runs contrary to the central assumptions of a more 'crime control'- oriented perspective, where ideas of people as rational-economic calculators have led to a focus on the deterrent threat and the extension of enforcement strategies (Hough et al., 2010).
} 
The procedural justice model has found support in empirical studies (e.g. Bradford et al., 2009; Bradford, 2014; Hough at al., 2010; Murphy \& Cherney, 2012; Sunshine \& Tyler, 2003; Tyler, 2006; Sargeant et al., 2014). However, Murphy and Cherney (2012) found that procedural justice actually had a counterproductive effect on the willingness to cooperate with the police among ethnic minorities who questioned the legitimacy of the law. To explain this, Murphy and Cherney discuss social distancing in relation to authorities, arguing that people who feel distant are more likely to display resistance towards authorities, and at the extreme level to disengage themselves from interaction with authorities. Murphy and Cherney (2012, p. 197) note, however, that this does not imply that the police should use hasher methods in order to achieve cooperation. Rather, the police have to acknowledge situations that may be experienced as exclusionary and unfair from the perspective of the people living in the area they work in, since procedural justice may be counterproductive partly because of a distrust towards the motives of the police resulting from past experiences and encounters.

Hirschman (1970) describes the concepts of "exit" and "voice" as two different strategies for handling dissatisfaction. As the word implies, "exit" is about leaving when you are not satisfied, while the strategy "voice" is instead about staying but trying to produce change from within (for example an organization). Although his discussion proceeds from an economic point of departure (and not at all from a procedural justice perspective) Hirschman (1970), along with others, has employed the exit and voice concepts in relation to many different situations (Agevall \& Olofsson, 2008). In this study, the youths' reactions to dissatisfaction may be seen as exit or voice strategies. These strategies may be important for how the interactions develop and, by extension, also for the experience of procedural (un)fairness.

Although the procedural justice perspective primarily focuses on the public's compliance with the law and cooperation with the police (Murphy \& Cherney, 2012; Sunshine \& Tyler, 2003; Tyler, 2006) police legitimacy is a central factor in relation to these outcomes. I would therefore argue that in relation to issues involving tense relations between those living in marginalized areas and the police who work in such areas, it is essential to focus attention on the importance of fairness and the lack of fairness for views of police legitimacy. My analysis will therefore proceed from the procedural justice perspective and look at what the youths' dissatisfaction is about in relation to these issues (e.g. is it about fairness or outcome?) and at how the police respond to this. Since the model also implies that it is the process that is important, and since the data are well suited to looking at processes, I will also analyze how the encounters evolve in relation to the police's responses to the youths' complaints.

\section{The Study}

Community policing and what has been labelled reassurance policing have both constituted ways of attempting to deal with problems of police legitimacy in socially disadvantaged areas (Adams, Roth, \& Arcury, 2002; Craig, Marnoch, \& Topping, 2010; Hawdon, Ryan, \& Griffin, 2003; Myhill \& Quinton, 2012; Sharp \& Atherton, 2007; Peterson, 2010; Wycoff \& Skogan, 1998). The fundamental elements of the policing tactic involved are visibility, accessibility and familiarity. In order to improve relations between the police and residents of socially disadvantaged neighbourhoods, and thus to increase police legitimacy, so-called local police offices have been established in Stockholm. The use of this approach differs somewhat from reassurance policing but the basic ideas are the same (Peterson, 2010). One of the principal tasks of the police offices is to establish contacts with youths in the area surrounding the respective offices. This article is based on a study in which the work of such police offices has been followed on a day-to-day basis, with a special focus on the work directed at youths.

The study material is comprised of participant observations. The officers have been followed throughout their shifts. Two different police districts in the county of Stockholm have been included in the study, and eight different police offices. I have participated in a total of 52 work-shifts, totalling 450 hours. I have accompanied the officers both during the day and the evening, but the vast majority of the shifts were in the evening and stretched into the night (until midnight or a few hours after midnight). The fieldwork was conducted during the spring and early summer of 2009 in one police district and during the spring and early summer of 2010 in the other. On most of the shifts in which I participated, I accompanied uniformed police officers, but I did on occasion accompany plain-clothes officers.

There are both similarities and differences between the areas covered by the police offices. By comparison with the population of Stockholm in general, a relatively large number of the residents of these areas are unemployed and have low average incomes, although this varies somewhat from one area to another. There are also differences in the areas' ethnic composition. There are both areas with a large proportion of residents with a foreign (primarily non-European) background, and areas with a relatively large proportion of residents who do not have this kind of background. Common to the majority of the areas are that they have relatively extensive crime-related problems, and that the relations between the residents and police who work there are characterised by some level of tension, which is also one of the reasons that police offices have been established in these areas. In this respect too, however, there are fairly substantial variations between the different areas. Some of the areas are among those re- 
garded as the most problematic in the Stockholm region. At the same time, it should be noted that the level of problems in these areas is substantially lower than that found in corresponding areas in the USA, for example.

In the context of ethnographic studies, the question of the researcher's effect on those who are being studied is an important one. Are these individuals presenting a facade or is the researcher able to observe how they would be behaving even if they were not being studied? It is likely that the presence of a researcher will influence what happens in the field (Holmberg, 2003; Sollund, 2007; Loftus, 2009). How much, and in what ways, will depend on a number of factors. When it comes to what police officers themselves choose to show or conceal, the issue of police behaviours that may cause problems for the police service itself is an important one. Experience from previous studies of the police shows that police officers have manifested such behaviours in the presence of researchers (Granér, 2004; Holmberg, 2003; Loftus, 2009; Sollund, 2007), but that it is likely that they conceal a great deal. It is therefore reasonable to assume that what I have been able to witness constitutes what might be termed "the most benevolent case scenario" on the part of the police. Having said this, it is important to remember that developing a certain degree of intimacy with the group under study is a precondition for successful ethnographic fieldwork. This means that an approach which involved endeavouring to avoid having any influence and to stay completely out of the way might, paradoxically, also result in worse data, i.e. in observations that provide less information about the situations of interest and the work of the police (Emerson, Fretz, \& Shaw, 2011; Holmberg, 2003; Sollund, 2006).

Another important issue, both for the possibility of conducting the study and for the quality of the data, is that of obtaining access to the field. Several police researchers have described mistrust on the part of the police and initiation rituals that the researcher has to go through in order to be accepted (Loftus, 2009; Holmberg, 2003; Finstad, 2000). With the exception of having been refused permission to conduct the research in certain of the police districts in Stockholm, the treatment I received from the police was far from antagonistic. The management were interested in the study and thought the research topic was important, as did the rank and file officers whom I followed. In obtaining access from the police management, I was allowed to freely select which police groups to follow, which areas to be in and which work shifts I wanted to attend. Nor was I "tested" prior to being accepted in any obvious way, at least as far as I could observe. This does not of course mean that the police officers were not aware of my presence and that they did not adjust their behaviour as a result, nor that I was not tested by them. I am quite sure that if I had failed to obtain the officers' approval, this would have influenced my possibilities for conducting the study.

All of the names used in the article have been invented and have been chosen to signify the sex and visible minority background (or not) of the individuals concerned (Mattsson, 2005), since these factors are assumed to have significance both for the form taken by the interactions and for how they should be interpreted. The names of police officers begin with $P$ and the youths' with other letters. The use of a name signifying that an individual appears to belong to an ethnic minority does not however mean that the individual was born outside Sweden. It is likely that the majority of the youths and police I have interacted with were born in Sweden. Nor should the names employed be associated with any particular part of the world or religious background.

In this article I focus on encounters in which youths confronted police officers and expressed their dissatisfaction with the latter's work, and situations in which youths have told me about such things. However, this does not include encounters in which someone is more or less unwilling about being subject to a police control, unless this was also accompanied by some form of accusation of wrongdoing or criticism of the police. These situations are excluded since such unwillingness is more about a wish to avoid control, rather than being a criticism of the police. During the time I spent following the police, just over 40 situations occurred during the 52 work-shifts in which youths expressed dissatisfaction with the police and their work in this way. These are the situations in focus here, but they are analyzed against the backdrop of the context of encounters between youths and police officers as a whole.

\section{4. "Even When We Haven't Done Anything!" Youth Dissatisfaction with the Police}

In most of the situations, the youths discuss their dissatisfaction with the police officers directly, but in some cases they have just told me about it when we have had the possibility to speak on our own. It is boys or young men that express complaints to the police in almost all of the situations. Based on the results of earlier research, this dominance of boys is not surprising. However, the almost complete dominance of boys is perhaps at least a little remarkable. On some of the occasions, it has not been possible (for me) to understand what the youths' dissatisfaction is about. It may be that the interaction was simply too brief, providing almost no information other than the manifestation of dissatisfaction, or that the youth simply pronounced that he did not like the police and then did not want to say any more when the police officers asked why. "I just don't, it's as simple as that" as one of them said. In some of the cases the youths merely express uneasiness at the 
police presence, not for any special reason, but rather because you never know what might happen if the police are present; they might just search you or check you out even if there is no reason for doing so, according to the youths. Such declarations suggest distrust in the police, even if no clear reason for this was expressed. Some of the situations involved complaints about the outcome of the police's work, e.g. that the police in general are incompetent, or more general accusations about the police just "harassing" people or conducting unnecessary controls. The reason for my not interpreting these last two types of situations as constituting unfair treatment is that there was no implication that this had been done in a selective way or to the youths themselves.

However, the situations described so far are exceptions, since almost three quarters of the encounters focused on some form of unfair treatment-of the youths themselves, people they know, or as a result of some more general group membership, such as accusations of the police being racist but not in relation to a specific person. From a procedural justice perspective, this focus is not surprising, and these also constitute the most important accusations for the police to deal with if they want to change others' opinions of them in a more positive direction. The remainder of this article will therefore concentrate on these situations.

\section{Experiences of Unfair Treatment and the Police Officers Responses}

A more general pronounced dissatisfaction in some of the areas is that the youths feel that the police focus particular, and too much, attention on their specific group of friends in relation to other youths in the area. This feeling is sometimes linked to the youths' ethnic minority background. One of the boys who told me about this, did so when we talked with each other alone and expressed it the following way.

Ali says, 'I don't like the police. We don't like the police here.' Tove: 'Ok, why is that?' Ali answers, 'No, but they are no good', and continues, 'But actually, it is like this,' and smiles, 'If you want their help, then you like them. So it is a bit of double standard,' laughing. Ali: 'If you understand?' I answer that I understand and smile back at him. Ali continues, 'But my dad would say that if you just behave lawfully, then you don't have any problems with the police. But it isn't as simple as that.' I ask him what he thinks about that, and what he thinks is problematic. Ali answers, 'We think that even when we haven't done anything, like up there, when I passed, then they started to ask me, just because I passed,' [talking about an earlier situation at which I was present]. Tove: 'Ok so you feel that they keep an eye on you, or?' Ali: 'Yes we do. It's a group here [the local police officers]; they have formed an opinion about certain of us, so to speak, about some of us.' (Field notes)

His feeling that his group of friends received special attention from the police was in my opinion wellfounded, since the police spoke about this group as one that they paid special attention to, and they also did so during my observations. All of the boys in the group had visible minority background as far as I could tell. This was of course not described by the police officers as constituting unfair treatment, but rather as strategic police work, which might motivate paying special attention to certain groups (Holmberg, 2003). Still, whatever the reasons, well-founded or not, this created a feeling of unfair treatment, at least for Ali. He also expressed this frustration directly to the police officers on a number of occasions by questioning why they were asking him, and not the others who were present, about a crime and a public order disturbance that had occurred during my observations. In one of these situations, the police officer simply motivated his actions, in a quite authoritarian and condescending manner, by saying that he knew Ali by name. On one of the other occasions, the police officer answered by asking Ali a rhetorical question: "But Ali, what is my job?" in a somewhat annoyed tone of voice. In the first situation, Ali responded with irritation, telling the police officer that he unfortunately (in an ironic tone of voice) wasn't the one who had thrown a stone. In the latter case he simply answered, "Yeah, yeah," and then let it go. It is clear that the police in these encounters do not work in line with ideas of procedural justice, since they, for example, do not take the time to explain why they are doing things the way they are. Further, the nonverbal communication between the parties involved was of significance for these situations, and served to emphasize the antagonism between Ali and the police officers.

Youths also questioned why they personally were given so much attention, and expressed feelings of unfairness in relation to this. Similarly, some of the youths also remarked on threatening behavior on the part of police officers, and on how police officers joked about the possibility of misusing their powers against the youths in question. There were also different types of accusations about the police working in a racist manner, or being racists. I won't describe these situations here since I have written about them elsewhere (Pettersson, 2013). ${ }^{3}$ But even though such situations were relatively unusual, allegations of this kind are serious and may be of substantial importance for feelings of unfair treatment.

\footnotetext{
3 Although such situations naturally constitute part of the analysis, I have chosen to present other examples here since these have already been described elsewhere.
} 
One situation that can illustrate several of the issues of unfair treatment that the youths confronted the police with in many encounters took place in a shopping mall. Since the situation is eventful, and also illustrates what some of the processes that take place in these encounters can look like, I will describe it quite thoroughly. The police officers had spent quite some time conducting a control focused on a migration case in a store. During the control, a group of boys had been banging on the windows and making a lot of noise outside. The police officers tell me that these are some of the youths in the area that they have an ongoing conflict with. I ask Pia what she thinks will happen when they come out and meet them (we have to pass the boys on the way to the police car). Pia smiles and says that they will probably shout words like 'police cunt' and 'police whore' after them, but will wait until after the police officers have passed so that they will not know who is shouting. When we enter the shopping mall, the boys are there, standing in small clusters. Paulinho and Pia stop a short distance from the youths and immediately someone quietly says something like 'police cunt'. The police officers (there were four officers present on this occasion) decide to talk to the youths. I listen to the conversation between Pia and Mahmoud, a 16-17 year old boy with visible minority background.

Pia starts talking about what someone in the group was shouting and also that they used to shout 'police whores', 'police cunts' and 'pigs' after them. Mahmoud argues that they [the youths] only want to be left alone. He returns to this several times. They are harassed by the police, he says. They want to be in the shopping mall but are not allowed to by the police. Pia argues that they are allowed to be there, as long as they don't do anything wrong. Pia also says that of course they should be left alone as long as they aren't doing anything. But when they do, like when they shout 'police cunt' and such, they aren't left alone. Mahmoud returns several times to a situation that had occurred two days previously, when he was turned away from the shopping mall by the police, specifically because he wasn't allowed to be there, not because of something he had done. (Field note)

Mahmoud talks quickly and agitatedly with a loud voice and the words gush out of his mouth. Pia talks more slowly and appears less agitated. Mahmoud expresses the feeling that the police harass the youths, and that this is not related to the actions of the youths themselves. It is clear that Mahmoud feels that he and his friends are treated unfairly by the police officers. But I also sense feelings of limited autonomy. According to Mahmoud, the youths are not responsible for what happens and it does not matter what they do, the po- lice will still turn them out of the shopping mall. Instead of discussing Mahmoud's accusations, Pia mostly focuses on what has just happened, i.e. calling the police ugly names. The encounter continues:

Mahmoud also speaks very agitatedly about Pelle having called him a 'baby's butt' ${ }^{4}$ when they met earlier [not clear to me when]. Pia objects that if Pelle did so, then it may have been unnecessary, but Mahmoud has to forget about it some time. Mahmoud then argues that it wasn't only that Pelle called him a 'baby's butt', but it was also how he acted. He was stopped and searched by Pelle, and held up against a wall right in front of people from his family.

The feeling of insult associated with being subjected to controls in front of others, particularly people known to the youths, is something that has also been noted in several other studies, and is something that is problematic from a procedural justice perspective. Mahmoud also refers to this incident repeatedly in the encounter with Pia. A number of the police officers I have followed have also been aware of the importance of avoiding this kind of control, and instead focus their attention on using strategies that allow the youths to 'save face' (Pettersson, 2012; see also Peterson, 2008). However, the situation that Mahmoud was talking about was described as quite the opposite. I had not been present when it happened; however, one of the police officers in the group spoke to me about this situation later that evening, when we were discussing the conflicts between the police officers and the youths in the area. We were having a conversation about the difficulties of knowing how to act in conflicts, whether the police should back off or go in more resolutely. In an earlier situation, they had let the youths go following some disturbances in a shopping mall, and just a few minutes later, the same youths had burned down a shop. He had thought a lot about whether they had acted in a good way or had been too lax, and whether they could have done things differently. This time (the situation Mahmoud had been talking about) the police had decided not to let the youths off. Instead they had put all of them up against the wall, and the police officer felt that this had been a better way to act. However, it is obvious from the discussion between Pia and Mahmoud that Mahmoud is of a different opinion. The police actions seem rather to have escalated the conflict between the police officers and the youths, as might have been expected from a procedural justice perspective. Once again, the non-verbal communications (e.g. putting them up against the wall) are important for the outcome. Returning to the encounter between Pia and Mahmoud, Mahmoud continues talk-

${ }^{4} \mathrm{~A}$ relatively mild term of derision meaning "childish". 
ing about how much he hates Pelle, and also states that some of the other police officers that work in the group with Pelle now act in the same way, even though they had previously been ok.

Mahmoud argues that those who work with Pelle become like him. He also tells Pia that 'I have nothing against you, you are ok,' 'but I hate him,' pointing at Paulinho, 'and her,' pointing at Perla. 'But he [identifying Pascal's overseas background] is ok. He has always been alright.' 'But her,' pointing at Perla, 'I could kill her if she wasn't a police officer, I hate her that much. You get it?' 'She was ok before, but then she started working with Pelle and became like him. They [Paulinho and Perla] play tough just like Pelle.'

Pia tries to say that he can't lump all of them together, but Mahmoud turns it around and says that that is the way the police treat the youths. If someone shouts something, all of them get the blame. 'You're ok, and him [points at Pascal], but as long as you're working with Pelle or him [Paulinho] or her [Perla], you will also get the blame.' (Field notes)

This illustrates how negative experiences of one police officer may be important for the opinion of other police officers. This is also in line with earlier research about opinions of the police, and is clearly related to feelings of unfair treatment. The encounter also shows the strength of feeling these experiences might evoke in the youths. After this, Pia starts discussing forgiveness between the youths and the police officers, and argues that both of them must draw a line under the things that have happened. Mahmoud has by this time quietened down a little, and when Pia asks him if they should keep going on like this forever he says, quite calmly, that he hopes not. After this Pia once again talks about the words the youths used against the police officers.

Pia: "but if you want to be left alone, I would just stand still and not say anything. You know that if you start shouting, you won't be left alone. If you want to be left alone keep quiet." Mahmoud also says that he knows that they do wrong; you shouldn't shout things after the police. "I know it's wrong and that we have also done wrong." He also says that this was the reason why they didn't come to the meeting ${ }^{5}$, because they know they have done wrong: "We have done almost as wrong as you have, I know that." Pia explains that nobody is forcing the youths to go to the meeting, Pia: "But I think

\footnotetext{
${ }^{5} \mathrm{~A}$ meeting was arranged between youths and the police in order to discuss the situation, but none of the youths wanted to attend. The meeting took place later on during my time in the area.
}

it would be better for everyone if the meeting could take place." (Field note)

Now there is more of a mutual understanding than a conflict between Mahmoud and Pia. He is calm, talks slowly without raising his voice, and the same is true of Pia. Mahmoud is even able to admit to some wrongdoing on the part of the youths. After this, the conversation ebbs out and after a while Mahmoud leaves. I then switch to the discussion between Paulinho and Perla and some other youths. These youths also articulate feelings of being treated unfairly. They talk about a boy in the area (not present at the moment) who is subject to controls time after time by the same officer, and they argue that this is because it has turned into a personal conflict for the police officer. However, Paulinho and Perla argue that this is because the youth in question has been in possession of narcotics, and that this makes it reasonable for the police officer to check him again. They try to explain why the police work as they do, without acknowledging that they may have acted incorrectly. The conversation is now calm and the impression is that the youths and police officers are listening to each other, even if they do not always agree. At about this point, two security guards show up in the shopping mall since it is closing time. One of the youths shouts that the guards want to close up and go home, and my field notes end as follows.

Everybody starts moving slowly out of the mall. Smiles on the faces of both youths and police officers. The feeling is one of mutual understanding and the atmosphere is quite pleasant. (Field note)

The non-verbal communication is significant for this long encounter between the youths and the police officers. For example: how the youths speak when they are annoyed at the beginning (e.g. fast, high pitched voice), how the youths bang on the window, how they move around during the interaction, how the police are quite calm and still in their movements, signaling that they are staying and listening. Finally, the smiles at the end signal something very different from the beginning of the interaction, and smiling together is an important part of how both parties define how the situation ends.

I observed several encounters that, like the one described above, started with antagonism and with expressions of complaints, and that then, following discussions between the police officers and the youths ended in a similar way to this one, in quite pleasant and friendly "chatting" (sometimes even with a sense of admiration towards the police officers). After the above encounter, I discussed it with Pia. She was quite content about how the situation had evolved, but she also though that the youths got stuck on things that are actually non-essential. She thinks that they can tend to rehash the same thing interminably. The question that 
arises here is, essential to whom? What is considered essential is not a neutral judgment, but depends on who defines it. The youths' complaint is defined as trivial from the police point of view, but it is obviously not trivial for Mahmoud and the other youths involved in the conflict. From a procedural justice perspective too, this would not be regarded as an unimportant question. It is rather one of the core questions for trust in the police and their legitimacy, since it is obvious that the youths identify themselves as being unfairly treated. It is also worth noting the amount of time and effort that the youths invest in trying to actually get along with the police officers and resolve the conflict. This was also the case in several other situations of this kind, and is something I will discuss in the concluding remarks.

Finally, I will provide an example of expressed dissatisfaction with the police in the absence of any discussion between the police officers and the youths. On this particular evening the police are plain-clothes officers and are patrolling in the vicinity of a block of flats when they pass a group of youths.

A group of youths are standing at the entry to the blocks and are kicking a soccer ball among themselves. When we turn up, one of the youths kicks the ball high in the air right at us. Patrik: "Look out!" Pauline has to move to avoid the ball hitting her. She does not attempt to kick it back, and just leaves it on the ground and continues walking. Nobody says or remarks upon anything, neither the police officers nor the youths. Patrik explains to me, after we have passed, that the boy kicking the ball was Enzo, a boy they have a lot of problems with. He belongs to the group of youths in the area who hate the police and he is one of those that refused to go to a meeting I attended between the police and youths in the area. I ask whether he understood that they were police officers and Patrik answers that all of them understood that straight away.

We start walking by a walkway along the center of the housing area. Suddenly there is a rustle in the bushes beside us. Some of the youths are standing in the center and have thrown something after us. It sounds like a stone or something. Patrik says, "Look out "cos here they come," in a calm, almost unaffected tone of voice. All of them continue at a slow pace as if nothing has happened. Nobody even looks at the youths as far as I can see, except for me. (Field notes)

It almost goes without saying that the non-verbal communication, from both sides, constitutes a central part of this communication. The youths' dissatisfaction is expressed only via non-verbal communication; but the opinion is still loud and clear. Similarly, the police officers' communication with the youths, since they ig- nore both them and the things they are doing, is also non-verbal, even though it might be less easy to interpret. These youths might be described as what Murphey and Cherney (2012) have referred to as disengaged, at least Enzo. The police officers describe him as the one who is part of the group of youths in the area who refuse to even talk to the police officers. From a procedural justice perspective this would suggest that trying to respond to him with procedural fairness may involve a risk of being counterproductive. However, I am quite sure that this was not the reason why the police officers did not stop and talk to the youths in this situation; instead they tried to appear unaffected by both the football incident and the things that were thrown after them. Later that night, when the incident was discussed with other police officers, who were not present at the situation itself but who work in the same area, it emerged that the police officers deliberately avoid acting in response to these kind of incidents, since they think it would serve to escalate the conflict with the youths in the area. This might imply that the only conceivable action is confrontation rather than discussion. One of the police officers also pointed out that this strategy can only be maintained as long as the youths do not hit a police officer with a stone because 'then it will be war'.

\section{Concluding Remarks}

The encounters between the police and the youths, in which the youths express complaints, are to a large extent about unfair treatment in one or another way, in line with the procedural justice perspective. The expressed unfairness may either be focused at a more general level towards the police as an institution or organization, or may be related to meetings with police officers. The encounters include examples of both. The complaints may of course sometimes be part of a jargon, but they mostly appear to reflect honest feelings of having received unfair treatment from the police in different ways. When it comes to the police officers' responses to the complaints, these include examples of both ignoring and avoiding a discussion of the complaints, and of acknowledging the youths' experiences and taking time to discuss them. Finally, the process that emerges from the complaints, via the police officers' reactions and the youths' responds to these reactions, can look quite different. In some of the encounters, the situations get stuck in antagonism (sometimes from both sides), in others they end in a relatively friendly state of getting along and understanding. Some of the keys to the latter kind of processes appear to be an acknowledgement of the youths' feelings, taking time to discuss matters that the youths are complaining about and discussing why the police work in the way they do. This is in line with the procedural justice perspective. The procedural justice perspective has 
been tested and supported empirically using quantitative data, and the qualitative data presented in the current study show that the perspective's central ideas also seem to be reflected in the processes that occur during encounters between police officers and (often) ethnic minority youths in marginalized areas.

The study also contributes by highlighting how significant non-verbal communication is for the experience of procedural fair treatment. Non-verbal communication is important to the way in which the encounters evolve, e.g. through the types of signals that the police officers communicate to the youths about their willingness to treat them with fairness and to acknowledge the youths' feelings and opinions. This is something that has been shown to be central for the possibility of turning an antagonistic situation into a less antagonistic one, but it also might be central for not making a situation antagonistic.

Some of the youths in the study have made serious allegations about experiences of unfair treatment, e.g. about ethnic discrimination, about being harassed time after time or about harsh and degrading treatment in front of others. In spite of this, the youths have often devoted much of their time and energy to attempting to get along with the police in their neighborhoods. The responses of youths in this study may be described as strategies of exit or voice. There are examples of exit strategies, such as the youths throwing things at the police or the ones who chose not to attend a meeting with the police. It should be noted that in a study such as this one, which involved accompanying the police, it is difficult to know how usual this is, since a successful exit strategy may make you "invisible" to the police. However, it is obvious that several of the youths whom I met in the study were choosing the voice strategy. They enter into a discussion with the police, they try to explain how they experience things, even very unpleasant experiences, and they do end up listening to the police when they in turn try to explain their point of view. The youths even get along with the police officers quite well afterwards, if they have been treated respectfully. This means that the youths, by choosing voice, actually provide the police with opportunities to produce change.

This suggests that it is quite possible to produce change, something that Myhill and Quinton (2012) also note. The youths' willingness to get along with the police in these areas should not be underestimated (see also Carr et. al 2007; Barrett, Fletcher, \& Patel, 2014). But this will not happen by itself. It requires a police force that takes youths' feelings of unfair treatment seriously and that is interested in including these youths instead of excluding them. I have also shown elsewhere that it requires a police force that recognizes the youths' situations and feelings of exclusion from society at large (Pettersson, 2013; see also Murphy \& Cherney, 2012).
Agevall and Olofsson (2008) suggest that Hirschman's analyses should be extended to include the dimension dependency. In this study I would argue that both the youths and the police officers, in different ways, are dependent on "getting along". The youths since their everyday life can otherwise be made quite troublesome by the police (see Pettersson, 2012), the police officers since they are dependent on cooperation from the policed in order to conduct their work. When the youths choose voice as strategy, this is more easily achievable, if the police just "catch the ball" by using the opportunities given to them.

\section{Acknowledgements}

I am grateful for all comments from colleagues at a seminar in Lund, and from two anonym reviewers. I am also grateful for excellent language editing by Dave Shannon.

\section{Conflict of Interests}

The author declares no conflict of interests.

\section{References}

Adams, R. E., Roth, W. M., \& Arcury, T. A. (2002). Implementing Community-Oriented Policing: Organizational Change and Street Officer Attitudes. Crime \& Delinquency, 48(3), 399-430.

Agevall, L., \& Olofsson, G. (2008). Förord till den svenska utgåvan av Sorti eller protest. In A. O Hirschman (Ed.), Sorti eller protest. Lund: Arkiv Förlag.

Barrett, G. A., Fletcher, S. M. G., \& Patel, T. G. (2014). Black minority ethnic communities and levels of satisfaction with policing: Findings from a study in the north of England. Criminology \& Criminal Justice, 14(2), 196-215.

Bowling, B., \& Weber, L. (2011). Stop and Search in global context: an overview. Policing \& Society, 21(4), 480-488.

Bradford, B. (2014). Policing and social identity: procedural justice, inclusion and cooperation between police and public. Policing \& Society, 24(1), 22-43.

Bradford, B., Jackson, J., \& Stanko, E. A. (2009). Contact and confidence: revisiting the impact of public encounters with the police. Policing \& Society, 19(1), 20-46.

Brunson, R. K. (2007). 'Police Don't Like Black People': African-American Young Men's Accumulated Police Experience. Criminology and Public Policy, 6(1), 71 102.

Brunson, R. K., \& Miller, J. (2006). Gender, Race, and Urban Policing: The Experience of African American. Gender \& Society, 20(4), 531-552. 
Carr, P. J., Napolitano, L., \& Keating, J. (2007). We Never Call the Cops and Here Is Why: A Qualitative Examination of Legal Cynicism in Three Philadelphia Neighborhoods. Criminology, 45(2), 445-480.

Chan, J. B. L. (1997). Changing Police Culture: Policing in a Multicultural Society. Cambridge: Cambridge University Press.

Craig, C., Marnoch, G., \& Topping I. (2010). Shared Leadership with Minority Ethnic Communities: Views Form the Police and the Public in the UK. Policing \& Society, 20(3), 336-357.

Dirikx, A., Gelders, D., \& Parmentier, S. (2012). PoliceYouth Relationships: A Quantitative Analysis of Flemish Adolescents' Attitudes toward the Police. European Journal of Criminology, 9(1), 191-205.

Emerson, R. M., Fretz, R. I., \& Shaw, L. L. (2011). Writing Ethnographic Fieldnotes. Chicago: The University of Chicago Press.

Finstad, L. (2000). Politiblikket. Oslo: Pax.

Granér, R. (2004). Patrullerande Polisers Yrkeskultur. PhD thesis. Lund: University.

Hallin, P. O., Jashari, A., Listerborn, C., \& Popoola, M. (2010). Det är Inte Stenarna som Gör Ont. Röster från Herrgården, Rosengård-om Konflikter och Erkännande. MAPIUS rapport 5. Malmö: Malmö Publikationer i Urbana Studier.

Hawdon, J. E., Ryan, J., \& Griffin, S. P. (2003). Policing Tactics and Perceptions of Police Legitimacy. Police Quarterly, 6(4), 469-491.

Hirschman, A. O. (1970). Exit, voice, and loyalty. Responses to declines in firms, organizations, and States. Cambridge: Harvard University Press.

Holmberg, L. (2003). Policing Stereotypes. Berlin \& Wisconsin: Galda und Wilch Verlag.

Hough, M., Jackson, J., Bradford, B., Myhill, A., \& Quinton, P. (2010). Procedural justice, trust, and institutional legitimacy. Policing, 4(3), 203-210.

Hurst, Y., Frank, J., \& Browning, S. L. (2000). The Attitudes of Juveniles toward the Police: A Comparison of Black and White Youth. Policing: An International Journal of Police Strategies \& Management, 23(1), 37-53.

Loftus, B. (2009). Police Culture in a Changing World. Oxford: Oxford University Press.

Mattsson, K. (2005). Diskrimineringens andra ansiktesvenskhet och "det vita västerländska. In P. de los Reyes \& M. Kamali (Eds.), Bortom Vi och Dom. Teoretiska Reflektioner om Makt, Integration och Strukturell Diskriminering. SOU 2005:41. Stockholm: Fritzes.

Murphy, K., \& Cherney, A. (2012). Understanding Cooperation with Police in a Diverse Society. British Journal of Criminology, 52(1), 181-201.

Myhill, A., \& Quinton, P. (2012). Confidence, Neighbourhood Policing, and Contact: Drawing Together the Evidence. Policing , 4(3), 273-281.

Peterson, A. (2008). Who "Owns" the Street? Ritual
Performances of Respect and Authority in Interactions between Young Men and Police Officers. Journal of Scandinavian Studies in Criminology and Crime Prevention, 9(2), 97-118.

Peterson, A. (2010). From Great Britain to Sweden: The Import of Reassurance Policing. Local Police Offices in Metropolitan Stockholm. Journal of Scandinavian Studies in Criminology and Crime Prevention, 11(1), 25-45.

Petrocelli, M., Piquero, A. R., \& Smith M. R. (2003). Conflict Theory and Racial Profiling: An Empirical Analysis of Police Traffic Stop Data. Journal of Criminal Justice, 31(1), 1-11.

Pettersson, T. (2012). Att balansera mellan kontroll och kontakt. Lokala polisers arbete med ungdomar. Lund: Studentlitteratur.

Pettersson, T (2013). Att hantera anklagelser om rasism i polisarbete. In A. Petersson \& M. Åkerström (Eds.), Den sorterande ordningsmakten. Studier av etnicitet och polisiär kontroll. Malmö: Bokbox förlag.

Quinton, P. (2013). The formation of suspicion: police stop and search practices in England and Wales. In L. Weber \& B. Bowling (Eds.), Stop and search. Police power in global context. London \& New York: Routledge.

Reiner, R. (2000). The Politics of the Police. Oxford: Oxford University Press.

Reitzel, J., \& Piquero, A. (2006). Does it Exist? Studying Citizens' Attitudes of Racial Profiling Police Quarterly, 9(2), 161-183.

Sargeant, E., Murphy, K., \& Cherney, A. (2014). Ethnicity, trust and cooperation with police: Testing the dominance of the process-based model. European Journal of Criminology, 11(4), 500-524.

Sernhede, O. 2007. Alienation is My Nation: Hiphop och Unga Mäns Utanförskap i Det Nya Sverige. Stockholm: Ordfront.

Sharp, D., \& Atherton, S. (2007). To Serve and Protect? The Experiences of Policing in the Community of Young People from Black and Other Ethnic Minority Groups. British Journal of Criminology, 47(5), 746763.

Skogan, W. G. (2012). Assessing Assymetry: the Life Course of a Research Project. Policing \& Society, 22(3), 270-279.

Sollund, R. (2006). Racialisation in Police Stop and Search Practice: the Norwegian Case. Critical Criminology, 14(3), 265-292.

Sollund, R. (2007). Tatt för en Annen. En Feltstudie av Relasjonen Mellom Etniske Minoriteter och Politiet. Oslo: Gyldendal.

Steffensmeier, D., Ulmer, J., \& Kramer, J. (1998). The interaction of Race, Gender, and Age in criminal sentencing: The punishment cost of being young, black, and male. Criminology, 36(4), 763-796.

Sunshine, J., \& Tyler, T. R. (2003). The role of procedural justice and legitimacy in shaping public support 
for policing. Law \& Society Review, 37(3), 512-548.

Tyler, T. (2006). Why people obey the law. Princeton and Oxford: Princeton University Press.

Wahlström, M. (2008). Se dig själv från den andra sidan. En sammanställning och analys av polisers intervjuer med "motparter". PHS serie i polisiärt arbete 2008:3. Solna: Polishögskolan.

Weitzer, R., \& Tuch, S. A. (2002). Perceptions of Racial Profiling: Race, Class, and Personal Experience.
Criminology, 40(2), 435-456.

Wortley, S., \& Owusu-Bempah, A. (2013). The usual suspects: police stop and search practices in Canada. In L. Weber \& B. Bowling (Eds.), Stop and search. Police power in global context. London and New York: Routledge.

Wycoff, M. A., \& Skogan, W. G. (1998). Community Policing. In D. H. Bayley (Ed.), What Works in Policing. Oxford: Oxford University Press.

\section{About the Author}

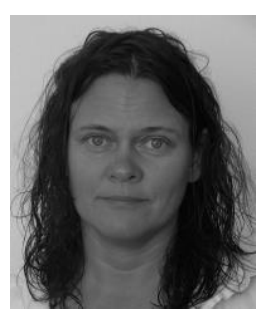

\section{Dr. Tove Pettersson}

Tove Pettersson is an Associate Professor at the Department of Criminology, University of Stockholm. Her research areas are police work, youth crime, discrimination within the justice system, and gender and crime. Her ongoing research is about the links between re-offending and openness during youth custody. Another publication by Tove Pettersson in the area of policing is, for e.g., "Belonging and unbelonging in encounters between young males and police office: The use of masculinity and ethnicity/race", published in Critical Criminology. 